\title{
Additions to the ascomycetous flora of the Canadian North
}

\author{
SEPPO HUHTINEN
}

\begin{abstract}
HUHTINEN, S. 1984: Additions to the ascomycetous flora of the Canadian North. - Karstenia 24: 1-11.

22 species of discomycetous fungi are reported from the timberline regions of Labrador, Quebéc, Manitoba and Northwest Territories (Mackenzie District), Canada. Dasyscyphys leucostomus Rehm, Poculum firmum (Pers.: Fr.) Dumont and Fimaria coprina Eckblad are new to North America. Other interesting records are Geopyxis cf. vulcanalis (Peck) Sacc. and Gloeotinia granigena (Quél.) T. Schumacher. The taxonomic status of Geopyxis majalis Fr. is discussed. The material includes possibly undescribed taxa of Dasyscyphella and Hyalopeziza.
\end{abstract}

Seppo Huhtinen, Department of Biology, University of Turku, SF-20500 Turku, Finland

While collecting seed material in Canada for the timberline arboretum, situated near Kevo Subarctic Research Station in northernmost Finland (cf. Kallio 1979), the author collected some fungi from Churchill, Manitoba $\left(58^{\circ} 46^{\prime} \mathrm{N}, 94^{\circ} 10^{\prime} \mathrm{W}\right)$ and Yellowknife, N.W.T. $\left(62^{\circ} 27^{\prime} \mathrm{N}, 114^{\circ} 21^{\prime} \mathrm{W}\right)$. Churchill is situated at the timberline while the town of Yellowknife lies ca. 150 kilometres SW of it. Part of the present collections date back to earlier Kevo expeditions, which were arranged, e.g., to the regions of Schefferville, Quebéc-Newfoundland $\left(54^{\circ} 49^{\prime} \mathrm{N}\right.$, $\left.66^{\circ} 48^{\prime} \mathrm{W}\right)$ and Fort Chimo, Quebec $\left(58^{\circ} 06^{\prime} \mathrm{N}\right.$, $\left.68^{\circ} 24^{\prime} \mathrm{W}\right)$. Part of these earlier collections have been studied by Huhtinen (1982). The working methods are similar to that study with the addition of observations using ultraviolet light (Desaga MinUVIS, 254 and $366 \mathrm{~nm}$ ). Also the ideas of Kohn and Kort (1975) and Nannfeldt (1976) have been followed. Observations and drawings are made from dried material. Unless otherwise stated the mountant used is lactophenol (with or without cotton blue) or Melzer's reagent.

Although the material includes some undescribed taxa, only a description in English is presented. The collections are mostly too sparse to make a good type. Being solitary and devoid of striking differences to existing species, they must await further collections to enlighten their range of variation.

\section{List of species}

\section{Pyrenomycetes}

Claviceps nigricans Tul.

N.W.T. Yellowknife, town area, shore of Back Bay, on fruits of Eleocharis palustris, $170 \mathrm{~m}, 31$.VIII.1981 Huhtinen $81 / 144 b$

The collection shows sclerotial stage only.

\section{Discomycetes \\ Pezizales \\ Pezizaceae}

Peziza sp. - Fig. 6

N.W.T. Yellowknife, town area, moist ground, pond margin with Typha latifolia and Carex aquatilis, $200 \mathrm{~m}, 31$.VIII.1981 Huhtinen 81/169.

Apothecia scattered, sessile, shallowly cup-shaped, with dark brown flanks and blackish, marginate disc up to $1 \mathrm{~cm}$ in diam when fresh, no violaceous or olivaceous tinge present. When dried, disc black, medullary excipulum brown and ectal excipulum black. Ectal excipulum of textura angularis - textura globulosa, walls slightly thickened, forming low, pyramidal pustules on the flanks. Medullary excipulum ca. $200 \mu \mathrm{m}$ thick, of textura intricata; when unrevived material is sectioned it results in structure close to textura epidermoidea; dark brown, inflated cells are frequent in medullary excipulum. Subhymenium very laborious to delimit, consisting of few layers of roundish cells. Hymenium $360 \mu \mathrm{m}$ thick. Asci $13 \mu \mathrm{m}$ wide, clearly I+ without $\mathrm{KOH}$ pretreatment, staining diffuse, mainly in the uppermost $20 \mu \mathrm{m}$ with strongest reaction in extreme apex, base without croziers. Spores uniseriate, ellipsoid, $18-19 \times 8-10 \mu \mathrm{m}$, first with two equal guttules (in lactophenol), later multiguttulate (then most often $19 \times 9.5 \mu \mathrm{m})$. Ornamentation up to $1 \mu \mathrm{m}$ high, consisting of small warts intermixed with short, irregular ridges, the largest warts appearing at spore ends, where the persistent perispore is most clearly observable. Paraphyses straight, septate, 2-5 $\mu \mathrm{m}$ wide, their apices brown in mass, colour not encrusted.

The apothecia appeared as those of Peziza brunneoatra Desm. in the field. The descriptions of Rehm (1896), Boudier (1905-1910, Pl. 298), 
Velenovský (1934) and Seaver (1961a) show a rather wide concept in this species. In a narrower sense $P$. brunneoatra is somewhat different from present collection. Dennis (1968), after studying Desmazières's original material, described the spores as broadly ellipsoid, warted and totally filled with small oil globules. These features also characterize Le Gal's (1941, Fig. 19) concept. A very similar description is given by Svrček (1976) under the conspecific Plicaria paludicola (Boud.) Vel. var. marginata Vel. The macroscopically close Peziza alaskana Cash has been shown to have reticulate spore ornamentation (Cash 1954, Pfister 1979), thus being clearly different.

I consider the present species to be very close to $P$. brunneoatra due to the multiguttulate, warty spores, similar colouring, and habitat. But it differs by elliptical spores.

\section{Helvellaceae}

\section{Helvella palustris Peck}

Man. Churchill, mire with monocotyledons and Larix, on tuft of various mosses, $10 \mathrm{~m}, 19$.VIII. 1981 Huhtinen $81 / 107$.

This species was earlier reported from the Schefferville area (Huhtinen 1982). Both collections are in accordance with Weber's (1972) description.

\section{Pyronemataceae}

Fimaria coprina Eckblad - Fig. 7

Que. Schefferville, SE end of John Lake, on bird dung, 570 m, 31.VIII.1979 Huhtinen \& Kosonen.

Apothecia gregarious, up to $4 \mathrm{~mm}$ in diam when dry, cupulate when young, later becoming discoid with a 0 to $80-\mu \mathrm{m}$-raised sterile margin, often with a constricted base. Flanks uneven, hairy, dark brown; disc reddish brown when dry; flesh thick, pure white. Ectal excipulum $80-100 \mu \mathrm{m}$ thick, brown, of textura angularis, covered with dark brown, encrusted hyphae running along the surface; anchoring hyphae hyaline, flexuous, walls slightly thickened; at the margin the structure is close to textura prismatica with cells parallel to the surface. Medullary excipulum $300-800 \mu \mathrm{m}$ thick, of textura intricata, hyphae $4-5 \mu \mathrm{m}$ wide to inflated, some deep staining in cotton blue, the cyanophilous matter concentrated on the inner wall. Subhymenium of tightly packed textura intricata, ca. $20 \mu \mathrm{m}$ thick, contrasting strongly to the medullary excipulum due to its strong colouring in cotton blue. Hymenium $120 \mu$ m thick. Asci cylindrical, ca. $120 \times 10 \mu \mathrm{m}$, I-. Spores ellipsoid, $10-12 \times 6-7 \mu \mathrm{m}$, smooth, showing no loosening layers in heated lactophenol, one de Bary bubble typical in lactophenol and Melzer's reagent, disappearing in gently heated water after which the spores appear as one-guttulate, the cyanophilous perispore is of temporary type lacking in mature, aguttulate spores. Paraphyses straight, 1.5-2.0 $\mu \mathrm{m}$ wide below, apex often $0.5-1.0 \mu \mathrm{m}$ wider, also often inflated just below the uppermost septum, apically brown to pale brown, branched or not.

The genus Fimaria now embraces twelve species (Brummelen 1962, Svrček \& Kubicka 1965, Eckblad 1968, Svrček \& Moravec 1969, Jeng \& Krug 1977, Torre \& Calonge 1978, Graddon 1980). Out of these
F. coprina was found to be closest to present collection and the examination of the holotype showed these collections to be conspecific. The only difference to Eckblad's (1968) material lies in its often lighter flanks. The difference in substrate is noteworthy; the type collection comes from paper mixed with human feces. Fimaria coprina was previously only known from the type collection.

Geopyxis cf. vulcanalis (Peck) Sacc. - Fig. 1 Man. Churchill, roadside with loamy gravel $200 \mathrm{~m} \mathrm{~S}$ of Northern Studies Centre, with small bryophytes only, e.g. Pohlia cf. annotina, $15 \mathrm{~m}, 24$.VIII.1981 Huhtinen 81/125.

Apothecia in dense clusters, first cupulate, then strongly flattened, discoid, rather fleshy, partly deformed by mutual pressure, up to $17 \mathrm{~mm}$ in diam when dried, disc intensely reddish orange when fresh with a lighter, crenulate margin. Stipe short, clearly defined, ca. $5 \times 2 \mathrm{~mm}$, totally immersed to the substrate. In dry material the flanks are dull yellow and much lighter than hymenium, smooth to unaided eye, minutely scurfy under hand lens. Ectal excipulum of irregular textura globulosa, ca. $50 \mu \mathrm{m}$ thick; at margin, between the hymenium and ectal layer, a thick layer of brownish textura prismatica can be observed. The lighter, crenulate margin is composed of tightly packed textura intricata, not infrequently intermixed with algae. Medullary excipulum of textura intricata, ca. $500 \mu \mathrm{m}$ thick. Subhymenium $30 \mu \mathrm{m}$ thick, brownish; hymenium 200 $\mu \mathrm{m}$ thick. Asci $190-200 \times 10 \mu \mathrm{m}$, I-, with prominent croziers. Spores ellipsoid with tapering ends, $15-18$ $\times 7.0-7.5 \mu \mathrm{m}$, acyanophilous when mature, i.e. the perisporium is of temporary type, last observable at spore ends, surface may be delicately wrinkled ( $X$ 1500 ) in well revived spores too, appearing as smooth with lower magnification, young spores devoid of any ornamentation, devoid of guttules, with a frequent de Bary bubble in some developmental stage, present in lactophenol and Melzer's reagent but disappearing in heated water. The number of nuclei not determined; after $\mathrm{KOH}$-pretreatment and acetocarmine staining spores and cells of paraphyses reveal several scattered, strongly staining granules each. In the same disc paraphyses range from cylindrical to apically irregular ones, the cylindrical ones dominate, 1.5$2.0 \mu \mathrm{m}$ wide below.

In the field this collection was momentarily considered as Aleuria, because there were at least 60 bright-coloured, flattened apothecia deformed by mutual pressure. The roadside was sparsely vegetated and only small bryophytes were abundant. Neither the substrate nor the bryophyte flora showed any traces of presence of charcoal.

The reddish-orange disc colour would suggest affinity to Geopyxis majalis Fr. However, after sectioning the Australasian collection of $G$. majalis listed by Rifai (1968), I can confirm Rifai's view that this species has clearly different ectal excipulum from that of present material and G. carbonaria (Alb. \& Schw.: Fr.) Sacc. The layer of prismatic cells perpendicular to the surface is even more conspicuous than in Rifai's Fig. 182. The outermost cell layer is composed of thick-walled cells similar to both taxa mentioned above. Toward the base of the 

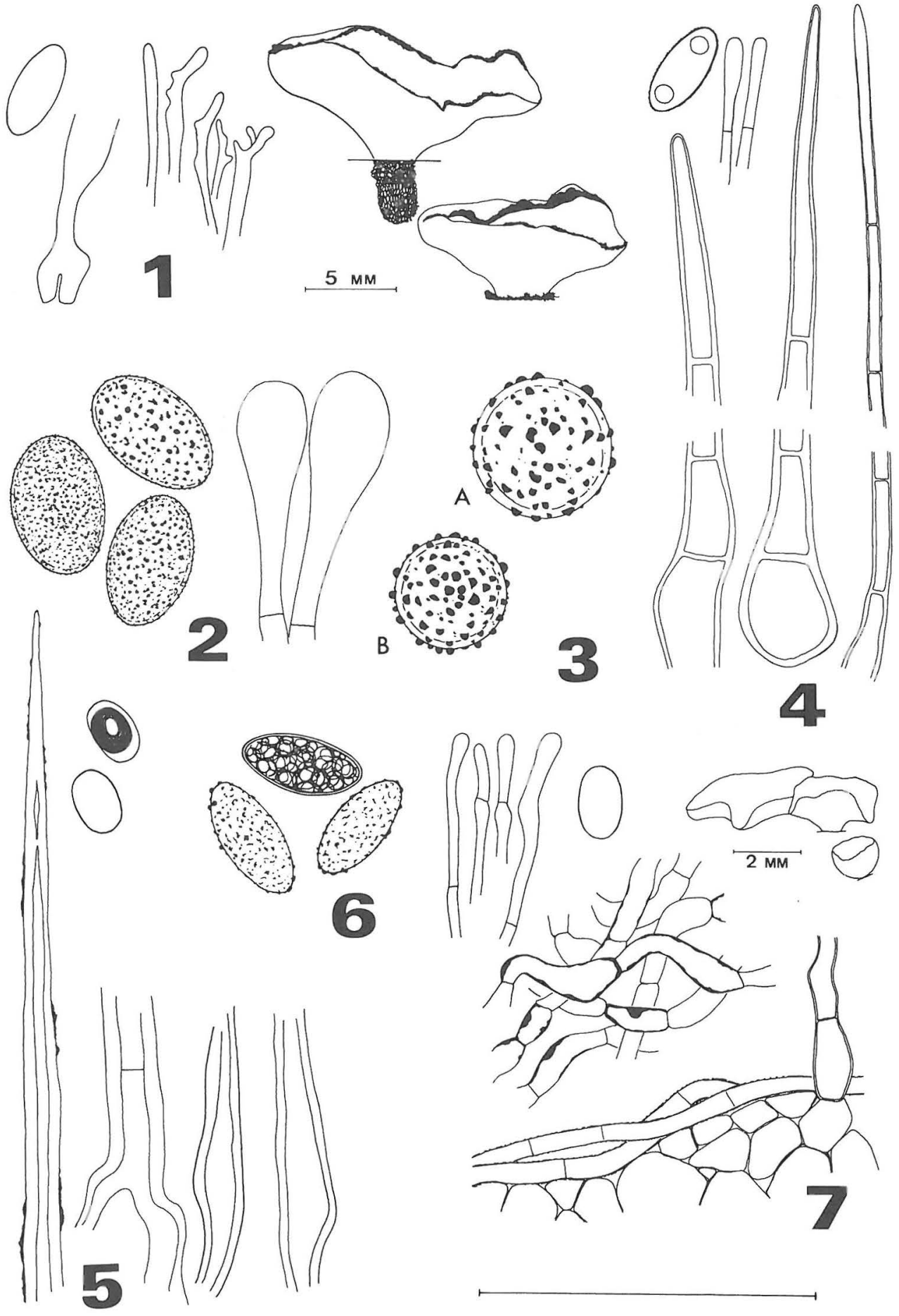

Figs. 1-7. Pezizales, scale $50 \mu \mathrm{m} .-1$ : Geopyxis cf. vulcanalis. - 2: Scutellinia kerguelensis aff. - 3: Scutellinia trechispora, a) Huhtinen 81/144a, b) Huhtinen 81/106. - 4: Trichophaea hemisphaerioides. - 5: Lasiobolus microsporus. - 6: Peziza sp. -7: Fimaria coprina. 
apothecium the excipulum is covered by $5 \mu \mathrm{m}$ wide, contorted, hyaline, and septate hyphae. G. majalis represents a species clearly separate from $G$. carbonaria. Its colouring together with substrate adds further proof to this view, although also $G$. carbonaria grows on non-pyrophilous sites (cf. Petersen 1970; also one personal collection on marine clay from Poste-de-la-Baleine, Quebéc).

Svrček (1979) deals with two species of Geopyxis, i.e., $G$. flavidula Vel. ( $G$. alpina Höhnel) and $G$. foetida Vel. The latter species is excluded from close relationship to present material due to the slender stipe, up to $10 \mathrm{~mm}$ long, dextrinoid excipulum and finely warted young spores. Due to its short stipe and strong flattening $G$. flavidula looks much alike present material, but it has a yellow disc and a very thin excipulum, being fragile according to Velen vský's (1934) original description. Although I have not seen any collections of these two species, I consider them quite different from present collection.

There still exists one possible taxon, namely Geopyxis vulcanalis (Peck) Sacc. Rifai (1968) stated this species as only critically different from $G$. carbonaria, but cited no specimens studied. Larsen \& Denison (1978) have kept the species separate. The description by Seaver (1961a) fits well and disc colour is stated as orange, thus bringing present collection near to $G$. vulcanalis. However, Groves \& Hoare (1954) laid no weight to disc colour in their study of northern material. A wider study is needed to decide the value of this taxon.

\section{Lasiobolus microsporus Bezerra \& Kimbrough} - Fig. 5

Que. Schefferville, SE end of John Lake, on bird dung, 570 m, 31.VIII. 1979 Huhtinen \& Kosonen.

Apothecia yellowish, up to $0.3 \mathrm{~mm}$ in diam when dried, sessile, irregularly discoid when fully developed. Hairs slightly ventricose, hyaline, most often $100-180 \times 5-10 \mu \mathrm{m}$ and aseptate, occasionally oneor two-septate, the very delicate septae occurring at the lower part of the hair, walls $2-3 \mu \mathrm{m}$ thick. Occasional gigantic hairs similar in shape but up to $500 \mu \mathrm{m}$ long, walls $4-5 \mu \mathrm{m}$ thick. A thin cyanophilous basal layer or scattered markings can be observed on the hair $(X 1500)$. Ectal excipulum of textura angularis to textura prismatica, cells horizontally oriented. Asci numerous, $90-120 \times 13-20$ $\mu \mathrm{m}$. Spores $10-11 \times 6-7 \mu \mathrm{m}$, with one de Bary bubble in lactophenol, Melzer's reagent and Congo red, disappearing in heated water. Paraphyses cylindrical, $2 \mu \mathrm{m}$ wide.

Because of the rather perfect agreement with the description given by Bezerra \& Kimbrough (1975), the material is referred to this species. The amount of cyanophilous markings was first considered to be smaller than in their material (cf. Fig. 14). This feature was, however, found to be affected by heating. In heated cotton blue the amount of these markings is diminished. Spore size excludes $L$. intermedius Bezerra \& Kimbrough and $L$. lasioboloides March. Hair characters together with ectal excipulum exclude L. trichoboloides Kahn \& Bezerra.
Pulvinula archeri (Berk.) Rifai

Nfld. Schefferville, Marble Lake, dolomite area, burned ground, $450 \mathrm{~m}, 12$. VIII.1967 Mäkinen 67/556.

Apothecia up to $1.5 \mathrm{~mm}$ in diam when dried, sessile, brownish orange. Ectal excipulum of textura angularis, medullary excipulum of textura intricata. Asci up to $150 \mu \mathrm{m}$ long, base gradually tapering, croziers present, sporal part $70 \mu \mathrm{m}$. Spores perfectly globose, $8 \mu \mathrm{m}$ in diam, smooth, in lactophenol with one to numerous guttules and/or one de Bary bubble. Paraphyses filiform, $1 \mu \mathrm{m}$ wide, strongly curved, mostly unbranched; if not, then with one apical branch only.

The material is well characterized by its small asci and spores and by the substrate. The only deviating feature from Rifai's (1968) and Pfister's (1976) description is the lack of strong branching in paraphyses.

Scutellinia kerguelensis (Berk.) Kuntze aff. - Fig. 2 N.W.T. Yellowknife, town area, shore of Back Bay, on moist silt/fine sand with Juncus alpinoarticulatus, Triglochin palustre, Eleocharis palustris and E. acicularis, $170 \mathrm{~m}$, 31.VIII.1981 Huhtinen 81/144.

Apothecia scattered, discoid, broadly sessile, up to $8 \mathrm{~mm}$ in diam when fresh, disc orange when fresh, shining yellow under UV-light when dried. Hairs concentrated to disc margin, 300-400 (-500) $\mu \mathrm{m}$, base $20-40 \mu \mathrm{m}$ wide, mostly simple, one third of them forked, hairs brown for their whole length, stiff, thick-walled, mostly 4-6 -septate; the scattered superficial hairs cylindrical, light brown, ca. 40-60 $\times 18-20 \mu \mathrm{m}, 1-2$-septate. Spores $18-21 \times 12-14$ $\mu \mathrm{m}$, elliptical, length/breadth $1.5-1.6$, very delicately ornamented, when mature filled with small guttules, outer spore layers not separating in heated lactophenol, eventually totally acyanophilous, but the cyanophilous perispore present to rather late age, wall $1 \mu \mathrm{m}$ thick. Ornamentation consisting of $0.1-$ $0.3 \mu \mathrm{m}$ high, discrete to confluent, irregular warts, maximally $1.5 \mu \mathrm{m}$ wide. Paraphyses subcapitate, apices up to $13 \mu \mathrm{m}$ wide.

$S$. kerguelensis is here interpreted as a taxon with also some basally forked hairs. There is a notable difference either in spore ornamentation or hair length to $S$. ampullacea (Limm.) Kuntze and $S$. subhirtella Svrček. They both have typically much coarser warts (cf. Kullman 1982). The same is true also with $S$. pseudoumbrarum Moravec (Dennis 1980). S. subcervorum Svrček has smaller and more elongate spores (Svrček 1971) although the present collection shows similar deviation from typical $S$. kerguelensis with very broad spores (Le Gal 1953). In all, it is often difficult, in spite of the many recent treatments, to place a single collection.

Because of the scant material the value of UVobservations is uncertain. Bright yellow colour was also present in $S$. cejpii and $S$. cf. ampullacea of the earlier material (Huhtinen 1982).

Scutellinia trechispora (Berk. \& Br.) Lamb. - Fig. 3 N.W.T. Yellowknife, identical site and ecology with preceding species, 31.VIII.1981 Huhtinen 81/144a. - Man. Churchill, Northern Studies Centre, ditch with standing water, on soil mixed with litter of Carex aquatilis var. 


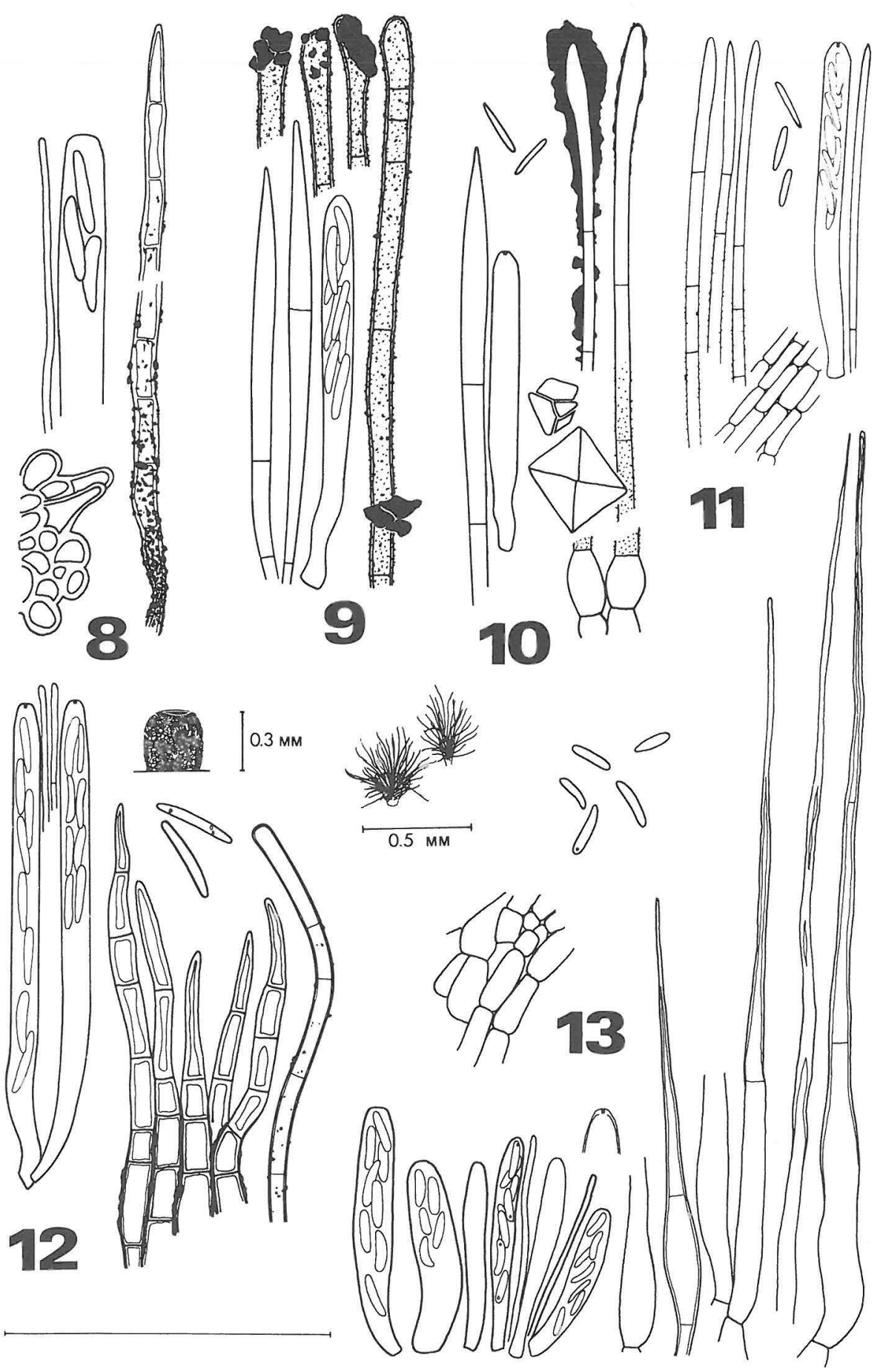

Figs. 8-13. Hyaloscyphaceae, scale $50 \mu \mathrm{m} .-8:$ Perrotia flammea, below detail from ectal excipulum. - 9: Dasyscyphus calyculiformis. - 10: Dasyscyphella nivea. - 11: Dasyscyphella sp. - 12: Dasyscyphus leucostomus, below left marginal hairs,
below right hair from the flanks. - 13. Hyalopeziza sp. 
aquatilis, also Dicranella sp. present, $10 \mathrm{~m}$, 19.VIII.1981 Huhtinen 81/106.

Apothecia scattered, $5-20 \mathrm{~mm}$ in diam when fresh, disc orange, colour same in dried material under UV-light. Hairs stiff, 3-5 -septate, up to 500 $\mu \mathrm{m}$ long, base simple, seldomly forked, superficial hairs present. Spores globose, $17-23 \mu \mathrm{m}$ in diam (ornamentation excluded), filled with small guttules. Warts discrete, low and rounded to more erect and round-topped, $0.5-1.0(-2.0) \mu \mathrm{m}$ high. Some spores with de Bary bubble in lactophenol. Paraphyses irregularly clavate.

There is a major difference in ecology and size of apothecia between these two collections. Yellowknife material was fully developed but not over $8 \mathrm{~mm}$ in diam, while collection 106 had almost three times larger apothecia. Differences in microscopical features are restricted to spores. The luxuriant apothecia (106) have spores measuring $17-18 \mu \mathrm{m}$ across (Fig. 3b); Yellowknife material with dwarfish apothecia has spores $21-23 \mu \mathrm{m}$ across (Fig. 3a). In both collections the spore wall is $1.0-1.5 \mu \mathrm{m}$ thick.

This variation is within the range given in earlier literature (cf. Le Gal 1966, Schumacher 1979a, Kullman 1982). Schumacher states the species as rare in Norway, probably preferring calcareous soil. At least the collection from Churchill - from an area with calcareous marine deposits on soil - adds some further evidence for this view.

Trichophaea brunnea (Alb. \& Schw.: Fr.) L. Batra \& S. Batra

Nfld. Schefferville, Marble Lake, on charcoal, $750 \mathrm{~m}$, 13.VII.1967 Mäkinen 67/586.

The margin of apothecia beset with brown, aculeate, septate, thick-walled hairs reaching $100 \mu \mathrm{m}$ in length. Flanks with brown, undulating, thinnerwalled, blunt hairs, $200-300 \mu \mathrm{m}$ in height. Spores globose, smooth, 13-14 $\mu \mathrm{m}$ in diam.

The combination of charcoal as substrate, globose spores and setose, brown hairs clearly delimit this species discussed by e.g. Rifai (1968).

Trichophaea hemisphaerioides (Mout.) Gradd. - Fig. 4

Nfld. Schefferville, Marble Lake, on charcoal, $750 \mathrm{~m}$, 13.VII.1967 Mäkinen 67/585.

Apothecia up to $5 \mathrm{~mm}$ in diam when fresh, disc light grey. Excipulum of textura angularis - textura globulosa, ectal parts brown with cells $10-20 \mu \mathrm{m}$ across, beset with superficial brown hairs varying in length and shape. The more stiff ones up to $430 \mu \mathrm{m}$ long, dark brown to the apex, 3-11 -septate, tapering to a pointed apex, basal cell inflated, $10-20$ $\mu \mathrm{m}$ wide, or base narrow and tapering, especially in the longer hairs, wall $1 \mu \mathrm{m}$ thick. On lower parts hairs more slender, $2-3 \mu \mathrm{m}$ wide, thinner-walled $(0.2-0.5$ $\mu \mathrm{m})$, flexuous, base simple or swollen, colour ranging from brown to hyaline. Apothecial margin composed of brown, club-shaped cells. Spores $12-15 \times 6.5-$ $7.0 \mu \mathrm{m}$, ellipsoid, biguttulate, minutely rough ( $X$ 1500 ) in cotton blue, de Bary bubbles occur sparsely in lactophenol, cyanophilous perisporium of temporary type. Paraphyses cylindrical, $2 \mu \mathrm{m}$ wide below, apically slightly widened (up to $3 \mu \mathrm{m}$ ).

The size of apothecia in this collection fits a large
Thichophaea abundans (Karst.) Boud. or a small $T$. hemisphaerioides and separation of these taxa without cultural studies is somewhat problematic. Features that have been stressed for $T$. abundans are small size, clear dimorphism in excipular hairs due to the short and basally inflated marginal hairs, and more clearly clavate paraphyses (cf. Karsten 1871, Svrček 1948, Webster et al. 1964, Binyamini 1972, Dennis 1981). Velenovský (1934) had material with clear difference in size of apothecia and some differences in hair characters, but his T. abundans was later shown to be conspecific with his $T$. hemisphaerioides (Svrček 1948).

In this collection both long and short hairs occur at the margin and an inflated basal cell can be encountered independent of hair position. The lack of dimorphism in hairs suggests affinity to $T$. hemisphaerioides, if this dimorphism really holds for $T$. abundans. Also the only slightly widened paraphysis apices show affinity to this species. Although the earlier descriptions state the spores smooth for both species, they are not smooth at least in $T$. hemisphaerioides (cf. Breitenbach \& Kränzlin 1981). Present material shows very minute warts in cotton blue. However, in $5 \% \mathrm{KOH}$ the spores are totally smooth, either because of the destruction of the possible, acyanophilous ornamentation or because of the swelling effect of that mountant.

Helotiales

Geoglossaceae

Spathularia flavida Pers.: Fr. - Fig. 14

Que. Labrador City, mossy Abies stand at the water tower, 19.VIII.1963 Kallio 560. - Man. Churchill, aged, mossy Picea glauca forest, 26.VIII.1981 Huhtinen 81/134.

The collection from Labrador City closely resembles the material cited in Huhtinen (1982). The apothecia in the other collection are similar in shape to Spathularia rufa Sw. but bright yellow hymenial colour and lighter, smooth stipe refer the collection to the species above.

\section{Spathularia rufa Sw.}

Que. Schefferville, Attikamagen Lake, Abies stand with a thick carpet of Pleurozium schreberi, 19.VIII.1963 Kallio 403 .

This collection, together with the earlier ones, is in accordance with, e.g., Maas Geesteranus's (1972) concept. This collection was also confirmed by Mrs. E. Ohenoja, Lic. Phil.

\section{Sclerotiniaceae}

\section{Gloeotinia granigena (Quél.) T. Schumacher}

Que. Fort Chimo, village area, on a fallen grass caryopsis in a ditch, 15 m, 26.VII.1967 Kankainen.

Apothecia clearly stipitate, disc $1.5 \mathrm{~mm}$ in diam when dried, dark brown and marginate, margin and uppermost part of the flanks concolorous with the disc. Stipe $1.5 \times 0.3 \mathrm{~mm}$ when dried, light brown, concolorous with the lower parts of the flanks. Ectal excipulum of parallel, thin-walled hyphae, measuring $20-30 \times 5-10 \mu \mathrm{m}$. This layer is covered by narrower, externally coarsely granulated,coloured hyphae. Medullary excipulum of textura porrecta, 
Fig. 14. Spathularia flavida, Huhtinen $81 / 134$, photo by collector.

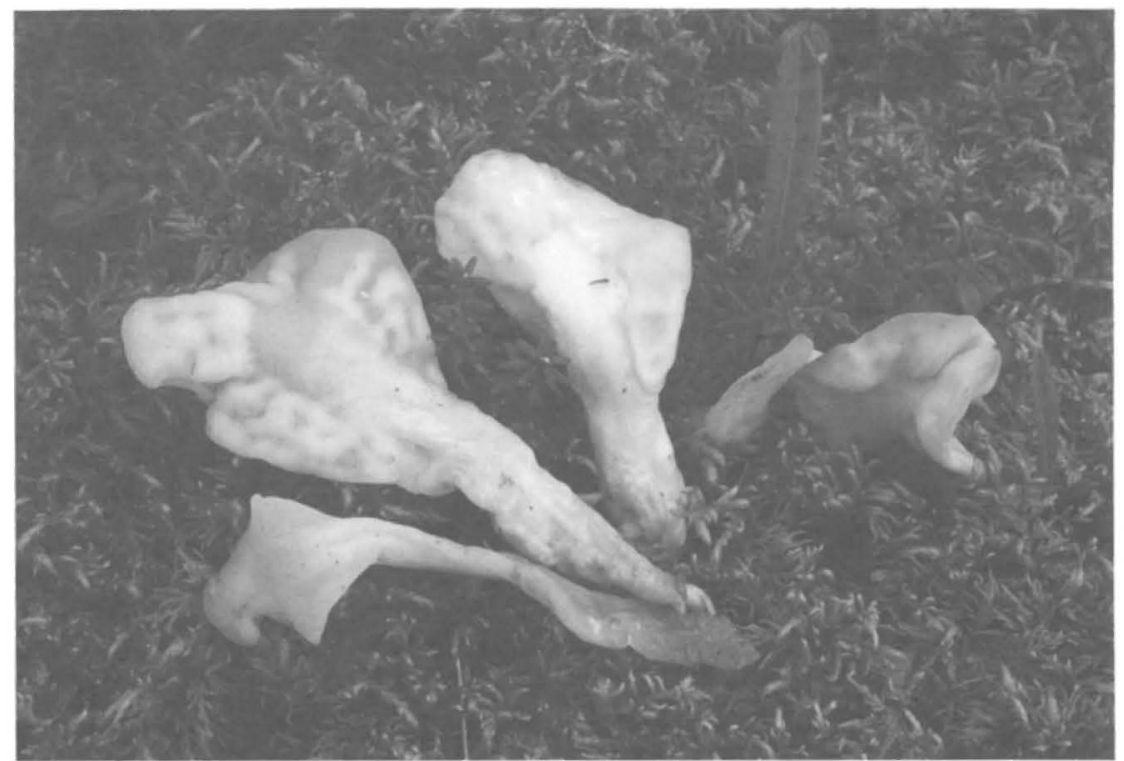

hyphae $2-3 \mu \mathrm{m}$ wide. Subhymenium amyloid. Asci $100-120 \times 8 \mu \mathrm{m}$, I- also after $\mathrm{KOH}$-pretreatment. Spores uniseriate, elliptic-inequilateral, $8-10 \times$ $4.0-4.5 \mu \mathrm{m}$, aseptate, acyanophilous, walls slightly thickened (up to $0.4 \mu \mathrm{m}$ ), no guttules in cotton blue, $\mathrm{KOH}$ or Melzer's reagent. Paraphyses cylindrical, $1.5-2.0 \mu \mathrm{m}$ wide, apex regularly $0.5-1.0 \mu \mathrm{m}$ wider, with brown contents and matrix.

Though no stroma formation could be detected in the badly preserved caryopsis, this specimen keys, on anatomical grounds, to above genus. There is no major deviation from the description given by Dennis (1956). The thickened spore wall seems to be present also at late stage. Some nomenclatoral notes on the species, synonymous to $G$. temulenta (Prill. \& Delacr.) M. Wilson et al., are presented by Schumacher (1979b). Reported by Seaver (1961b) from Oregon. This species is rarely collected in North America and no material is deposited in DAOM or CUP (Dr. Kohn, in letter).

Poculum firmum (Pers.: Fr.) Dumont

Que. Schefferville, Attikamagen Lake, on wood of Alnus crispa, 500 m, 5.VIII.1967 Kankainen.

Ectal excipulum made of three layers; the innermost of light brown, parallel hyphae, 3-4 $\mu \mathrm{m}$ wide; outside this is a gelatinized, hyaline, more short-celled layer, cells $20-25 \times 8-10 \mu \mathrm{m}$; the covering layer made of narrow, brown hyphae. Medullary excipulum of hyaline textura intricata, subhymenium brownish. Asci $140 \times 11 \mu \mathrm{m}$, I+ without KOH-pretreatment. Spores irregularly biseriate, elliptic-fusoid, inequilateral, 19-23 $\times 4-5$ $\mu \mathrm{m}$, 3-septate when aged and then typically producing apically subglobose conidia. Paraphyses cylindrical.

The material is in close agreement with White's (1941) description based on European material. At that time reliable records on this species from North America were still lacking. The earlier records were based on Rutstroemia macrospora (Peck) Kan. (syn. Ciboria peckiana (Cke) Korf), which lacks the gelatinized layer in ectal excipulum. Based on Kohn's (1982) view this would be the first record of Poculum firmum from North America.

\section{Hyaloscyphaceae}

Dasyscyphus calyculiformis (Schum.: Fr.) Rehm - Fig. 9

Nfld. Schefferville, Astray Lake, on twigs of Alnus crispa, 600 m, 4.VIII. 1967 Kankainen.

Apothecia stipitate, externally brown and hairy, ca. $1 \mathrm{~mm}$ in diam. Disc yellowish when dry, stated as greyish in fresh material, stipe $0.3 \mathrm{~mm}$ long. Ectal excipulum of textura prismatica - textura angularis, cells up to $15 \mu \mathrm{m}$ long. Hairs up to $170 \times 5 \mu \mathrm{m}$, wall slightly thickened, mostly $0.5 \mu \mathrm{m}$ but occasionally up to $1 \mu \mathrm{m}$, multiseptate, brown, covered with minute, hyaline granules, except for the slightly broadened apex, which is usually hyaline and bearing conspicuous crystal masses, occasionally crystals present also in lower parts, no purple stain excuded in $\mathrm{KOH}$. Asci $60-80 \times 5-6 \mu \mathrm{m}$, It without $\mathrm{KOH}-$ pretreatment. Spores irregularly biseriate, cylindricalsubfusoid, $11-14(-16) \times 2 \mu \mathrm{m}$, aseptate. Paraphyses lanceolate, basally 1-septate, $4 \mu \mathrm{m}$ wide, exceeding the asci by $20 \mu \mathrm{m}$.

The present collection raises some problems in the classification of Dasyscyphus calyculiformis and its segregates. Out of these both var. latebricola Rehm and D. clandestinus (Bull.: Fr.) Fuck. are kept separate mainly because of smaller spores and partly specific substrates. Also they both lack purple dye in $\mathrm{KOH}$. The former, discussed by Dennis (1963) and raised to specific rank by Raitviir (1970), is possibly confined to Ericaceae. The latter is said to occur on Rubus and other rather woody herbaceous stems. Ecologically it could be considered as lignicolous and perhaps not so far from $D$. calyculiformis. $D$. 
populicola (Seaver) McKnight is said to differ from present species in the substrate, lack of purple dye in $\mathrm{KOH}$ and in slightly smaller spores measuring $7-9$ $(-13) \times(1.8-) 2.0-3.0(-4.0) \mu \mathrm{m}$ (Haines \& McKnight 1977).

Present material definitely lacks any traces of purple dye in $\mathrm{KOH}$. This was carefully verified using both low and high magnification and different concentrations of $\mathrm{KOH}$. The substrate is Alnus, so this cannot be $D$. populicola sensu Haines \& McKnight. A happier solution than considering this collection once again as a new substrate-specific taxon, is to allow D. calyculiformis more variation in the substrate, chemical and spore characters.

No clear morphological differences to Finnish reference material, staining in $\mathrm{KOH}$, could be detected. I also have five additional collections from Poste-de-la-Baleine to be treated in a later paper. Three of these are similarly on Alnus, one comes from driftwood and one from wood of Populus tremuloides. None of these collections excude dye thus suggesting a wider concept of present species.

Dasyscyphus leucostomus Rehm - Fig. 12 Nfld. Schefferville, Astray Lake, on dead stems of Heracleum maximum, 4.VIII.1967 Mäkinen 67/1369a.

Apothecia cupulate, sessile, up to $0.3 \mathrm{~mm}$ in diam when dried, externally violet-brown, inside whitish due to small granules or spores, disc light yellow, margin white, fringed with hyaline, irregularly tapering, septate, $30 \mu \mathrm{m}$ long hairs, their walls $0.5-$ $1.0 \mu \mathrm{m}$ thick, basally brown and violet encrusted. Hairs covering the flanks correspondingly basally brown to violaceous encrusted, this formed by minute granules unevenly distributed and of varying size (unheated water), their amount easily diminished in other mountants or when heated; these hairs up to $200 \mu \mathrm{m}$ long, $2-4 \mu \mathrm{m}$ wide, wall $0.5-1.0 \mu \mathrm{m}$ thick, septal intervals $10-15 \mu \mathrm{m}$, no colour reaction in $\mathrm{KOH}$. Ectal excipulum of textura prismatica, cells $8-10 \times 4 \mu \mathrm{m}$, brown-encrusted. Asci $60-80 \times 4-5$ $\mu \mathrm{m}, \mathrm{I}+$ only after $\mathrm{KOH}$-pretreatment, colouring very deep, appearing as two thick lines. Spores cylindricalsubfusoid to fusoid, $11-13(-14) \times 1.5-2.0 \mu \mathrm{m}$, mostly aseptate, rarely 1 -septate, aguttulate or with one to three irregularly spaced small guttules in cotton blue and Melzer's reagent. Paraphyses cylindrical, $1.0-1.5 \mu \mathrm{m}$ wide, multiseptate, apex rounded, not tapering.

The material was found to be exactly identical with collections determined by Rehm (Linhart, Fungi Hungarici 287 on Delphinium, 61 on Cimicifuga) and a collection from northern Finland (on Geum rivale, TUR 39261). The description of Rehm (1896) fits well, though he did not note the clearly different marginal hairs and states the hymenium as rosy. The change of hair contents to violaceous in $\mathrm{KOH}$ (Raitviir 1970) could not be observed in any collection.

D. leucostomus is previously unreported from North America. The author has also an ample collection from Poste-de-la-Baleine area, and this one is also on Heracleum maximum. Rehm (1896) states this fungus to be alpine.
Both Dasyscyphus solenia (Peck) Dennis and Peziza cenangioides Ellis might be confused with this species in the field. The former species has wider and more closely septate, rather short hairs. The hairs of $P$. cenangioides are more like those of $D$. leucostomus, but they are stated as thin-walled and shorter. In all $P$. cenangioides is more close to present material than D. solenia (cf. Seaver 1961b, Dennis 1963).

Dasyscyphus virgineus (Batsch: Fr.) Fuck.

N.W.T. Yellowknife, town area, on wood of Alnus crispa, 31.VIII.1981 Huhtinen 81/149; buried twig, 31.VIII.1981 Huhtinen $81 / 158$.

Apothecia clearly stipitate, up to $1 \mathrm{~mm}$ in diam and pure white when fresh, may become pale brownish when dried, stipe firm to delicate. Hairs ca. $100 \times 3$ $\mu \mathrm{m}$, thin-walled or wall up to $0.4 \mu \mathrm{m}$ thick, evenly and totally granulated, septate, cylincrical or apex slightly widened or tapering, not bearing crystal masses or excuding resinous matter. Asci $50 \times 5 \mu \mathrm{m}$, $\mathrm{I}+$ without $\mathrm{KOH}$-pretreatment. Spores $6-8 \times 1.5-$ $2.0 \mu \mathrm{m}$, cylindric-subfusoid, aseptate. Paraphyses lanceolate, $2.5-4.0 \mu \mathrm{m}$ wide, exceeding the asci by $10-20 \mu \mathrm{m}$.

The collections are more robust than the forms found on catkin scales (cf. Huhtinen 1982). They bear common features in hair length and lanceolate paraphyses, thus being separate from $D$. brevipilus Le Gal. Collection 149 has slightly thickened hair walls; this feature is shown also by Dennis (1949, Fig. 4e). Hair apices show variation. The brown colour of some dried apothecia is not likely to be of diagnostic value.

Dasyscyphella nivea (Hedw. fil.: Fr.) Raitv. - Fig. 10 Nfld. Schefferville, Marble Lake, on dead, woody stems of ?Rubus, 500 m, 12.VII.1967 Heikkilä \& Kankainen.

Apothecia stipitate, yellowish when dried, $0.3 \mathrm{~mm}$ in diam. Hairs $80-100 \times 2 \mu \mathrm{m}, 5-6$-septate, wall slightly thickened $(0.3 \mu \mathrm{m})$, minutely granulated except the upper $30-50 \mu \mathrm{m}$ which is totally smooth and stains more intensively in cotton blue, apex typically clavate, $3-4 \mu \mathrm{m}$ wide, covered by an orange-yellow, amorphous substance, basal cell narrow to inflated. In heated lactophenol loose, hyaline crystals present. Asci $40 \times 5 \mu \mathrm{m}$, I+ without $\mathrm{KOH}$-pretreatment. Spores cylindric-subfusoid, $6-7$ $\times 1-2 \mu \mathrm{m}$. Paraphyses lanceolate, $3 \mu \mathrm{m}$ wide, $1-$ septate, exceeding the asci by $15 \mu \mathrm{m}$.

The genus Dasyscyphella now includes seven species out of which $D$. nivea is well characterized by the orange-yellow substance often affecting the colour of dried apothecia. Due to the lanceolate and clearly exceeding paraphyses the material comes closest to D. crystallina (Fuck.) Raitv. which apparently is conspecific with $D$. nivea. The two recently described species, $D$. montana Raitv. and $D$. angustipila Raitv., remain white when dried. Also $D$. dryina (Karst.) Raitv. is close to present species, but has larger spores $(9.6-11.0 \times 2.0-2.5 \mu \mathrm{m})$ and does not excude resin (Dennis 1949, Raitviir 1977).

Under UV-light the apothecia were dull yellowish and a slight colour difference could be detected relative to the species treated below. 
Dasyscyphella sp.

- Fig. 11

Que. Fort Chimo, Highfall Creek, on decorticated wood of Alnus crispa, $50 \mathrm{~m}, 2$.VIII.1967 Kankainen.

Apothecia gregarious, stalked, $0.2 \mathrm{~mm}$ in diam and white when dried. Hairs $80-120 \times 2 \mu \mathrm{m}, 5-6-$ septate, wall $0.3 \mu \mathrm{m}$ thick, acyanophilous, granulated below, upper $30-40 \mu \mathrm{m}$ smooth, apex slightly inflated to tapering, not excuding any coloured substance. No loose crystals present in heated lactophenol. Asci $40-55 \times 4-5 \mu \mathrm{m}$, I+ without KOH-pretreatment. Spores usually obliquely and irregularly biseriate, cylindric-subfusoid, $6-7 \times 1-2$ $\mu \mathrm{m}$. Paraphyses narrowly lanceolate, up to $2.5 \mu \mathrm{m}$ wide, not exceeding the asci or only by $5 \mu \mathrm{m}$.

Possibly this scarce material represents a new taxon. It is closest to D. angustipila Raitv., but has narrower spores and hair apices. In the present collection some hairs may be subclavate with an apex $0.5 \mu \mathrm{m}$ wider than lower parts, but the characteristic hairs taper at their apices. Raitviir (1977) had seven collections from Eurasia when describing $D$. angustipila and he reported only subclavate hairs.

Under UV-light the apothecia show yellow colour, slightly brighter than that of Dasyscyphella nivea.

\section{Hyalopeziza sp.}

Que. Schefferville, bog $\mathrm{N}$ of the airstrip, on rotten, decorticated wood, $500 \mathrm{~m}, 10$. VII.1967 Heikkilä \& Kankainen.

Apothecia cupulate, with a short, tapering base, appearing white due to a dense covering of white hairs, but excipulum light brown when dried, disc up to $0.3 \mathrm{~mm}$ in diam when dried. Excipulum of somewhat irregular textura prismatica, hyaline under microscope, dextrinoid. Hairs frequently up to $200-$ $250 \mu \mathrm{m}$ long, mostly hyaline but may sometimes attain brownish colour in over-aged apothecia, smooth, tapering to a filiform or blunt apex, somewhat undulating, regularly with a swollen base, dextrinoid, $0-2(-4)$-septate, basally thin-walled, upper wall thicker and lumen even disappearing, septae thin, wall staining in Congo red, hyaline in cotton blue, structurally stable in $\mathrm{KOH}$. Asci varying in shape, $30-35 \times 4-7 \mu \mathrm{m}$, I+ without $\mathrm{KOH}-$ pretreatment. Spores cylindric-subfusoid, 7-10 $\times$ $1.5-2.0 \mu \mathrm{m}$, ?aseptate (I have a single observation of a septum), sometimes with minute guttules. Paraphyses cylindric, not exceeding the asci. Apothecia under UV-light yellowish.

Due to the presence of thick-walled and septate hairs the material is placed to the present genus. Septal thinness, stability in $\mathrm{KOH}$ and the dextrinoid reaction of hair wall are also typical features of the genus (Dennis 1963, Raschle 1977, Korf \& Kohn 1980).

The present material is most characteristic due to its basally thin-walled and swollen, very long hairs. They are always clearly tapering, typically filiform at their apices. The dextrinoid reaction is clear throughout, only areas below the swollen hair base do not stain so strongly. Often the hairs are aseptate and at the same time devoid of pseudoseptae too. The dextrinoid reaction in the excipulum is much weaker than in the hairs resulting in light red-brown colour.
This reaction seems to be an unreported feature in Hyalopeziza Fuck.

The hair characters, if stable in culture, suggest a new taxon. But it should be noted that this fungus is also related to the genus Hyaloscypha, where dextrinoid and partly solid hairs do occur. Also the faint colour of excipulum and its dextrinoid reaction might turn out to be useful characters when additional material is found. In the system by Korf \& Kohn (1980) the species belongs to Hyalopeziza subg. Hyalopeziza.

The hairs of Hyaloscypha mirabilis Vel. (Velenovský 1934: 283) bear a close resemblance to present material. Although no type material remains in Prague this foliicolous taxon is most likely conspecific with Hyalopeziza ciliata Fuck. This same taxon was also described under Hyaloscypha subtilis Vel. and Zoellneria acerum Vel. (Dr. Svrček, in letter).

Perrotia flammea (Alb. \& Schwein.: Fr.) Boud.

N.W.T. Yellowknife, town area, on decorticated branch of Alnus crispa, $180 \mathrm{~m}$, 31.VIII.1981 Huhtinen 81/148.

Apothecia first subglobose, then expanding, sessile, up to $2 \mathrm{~mm}$ in diam when fresh, covered by bright orange to deep red hairs, hymenium yellowish when dried, flanks often worn out of hairs. Ectal excipulum of two layers; inner layer of textura oblita, walls highly gelatinized; outer layer of blackish brown textura globulosa - textura angularis, walls clearly thickened. Medullary excipulum of slightly gelatinized textura intricata, subhymenium undiscernible. Surface densely covered with hairs, hyaline in their most part, only few basal cells brown, $150-200 \times 3-4 \mu \mathrm{m}$, multiseptate, blunt, loosely covered with variable orange granules for their whole length or less, wall of uneven thickness, $0.5-1.0 \mu \mathrm{m}$ to even pseudoseptate. The granules dissolve immediately when $5 \% \mathrm{KOH}$ is added, simultaneously abundant purple dye is formed, these granules dissolve also in heated lactophenol. In addition to coloured granules, the hairs are covered with minute, hyaline granules, firmly attached and unsoluble. Outer surface also with numerous, hyaline crystals, unsoluble in $\mathrm{KOH}$. Asci $80-100 \times 7 \mu \mathrm{m}$, wall uniformly ca. $0.5 \mu \mathrm{m}$ thick, apex broadly rounded, I-. Spores cylindric-subfusoid, straight to curved, $12-14(-17) \times 2-3 \mu \mathrm{m}$, finally 1 -septate. Paraphyses cylindrical, obtuse, $1-2 \mu \mathrm{m}$ wide, not exceeding the asci.

The apothecia grew in large swarms on weathered, decorticated branches, which were at the beginning of their decay and still hard and notably dry. Hair colour varies from deep red to bright orange; the latter dominating. This feature seems to be problematic, because Haines \& McKnight (1977) stressed the orange to brown hairs of Perrotia populina (Seaver) Dennis as a separating feature to $P$. flammea with rust red hairs. However, in the present material and additional collections from northern Finland the hairs of $P$. flammea are typically orange to the unaided eye.

The description by Haines \& McKnight (1977) 
offers, however, other differences to $P$. flammea. Their material did not yield any colour in $\mathrm{KOH}$ and the hairs are described as brown-walled. This is the case also in descriptions by Seaver (1961b) and Dennis (1963). When hairs of $P$. populina are notably brown-walled it yields in difference to other species in this genus (cf. Dennis 1958, 1963). Both Dennis and Haines \& McKnight described the spores of $P$. populina as aseptate. This is the case in majority of spores of the present collection. Scattered one-septate spores, with a septum clearly observable only after a strong staining in cotton blue, do occur free from the asci.

In all, Perrotia populina is a still closer relative to the present species than $P$. aurea (Massee) Dennis, different in hair colour and lack of dye in $\mathrm{KOH}$ (cf. Dennis 1958). Perrotia succina (Phill.) Dennis differs in having yellowish hairs to unaided eye and under microscope (Seaver 1961b, Dennis 1963).

\section{Leotiaceae}

Cudonia confusa Bres.

Que. Schefferville, Attikamagen Lake, spruce forest, $500 \mathrm{~m}$, 5.VIII.1967 Kankainen; also Kallio 101. - Nfld. Labrador City, Abies strand near water tower, 19.VIII.1963 Kallio.

Paraphyses cylindric, curved, tip not swollen. Colour of dried apothecia is not always a useful character in separating this species from Cudonia circinans (Pers.: Fr.) Fr. Blind test suggests that paraphyse apices may be a better feature to use.

The apothecia of Kallio's collection (101) showed clear green-yellow colour in stipe under UV-light. This feature was not encountered in other collections of Cudonia from northern Canada and Finland.

Acknowledgements. My deepest gratitude goes to prof. Paavo Kallio, who has arranged these Kevo projects during which the collections were made. I am also grateful to following persons who gave valuable advice and help or made important collections: Miss Heli Heikkilä, Lic.Phil., Mr. Lasse Kosonen, Dr. Yrjö Mäkinen, Mrs. Esteri Ohenoja, Lic.Phil., and Dr. Mirko Svrček. Curators of Fungi in $\mathrm{K}$ and $\mathrm{O}$ are thanked for arranging the essential loans.

\section{References}

Bezerra, J.L. \& Kimbrough, J.W. 1975: The genus Lasiobolus (Pezizales, Ascomycetes). - Canad. J. Bot. 53(12): $1206-1229$

Binyamini, N. 1972: Trichophaea abundans (Karst.) Boud. = Anthracobia humillima Malencon. - Bot. Tidskr. 67: $154-158$.

Boudier, E. 1905-1910: Icones Mycologicae. - Paris.

Breitenbach, J. \& Kränzlin, F. 1981: Pilze der Schweiz 1. Ascomyceten. - 313 pp. Luzern.

van Brummelen, J. 1962: Studies on discomycetes 2. On four species of Fimaria. - Persoonia 2(3): 321-330.

Cash, E.K. 1954: Some discomycetes new to Alaska. - J. Washington Acad. Sci. 44(2): 44-46.

Dennis, R.W.G. 1949: A revision of the British Hyaloscyphaceae with notes on related European species. Mycol. Pap. 32: 1-97.

- 1956: A revision of the British Helotiaceae in the Herbarium of the Royal Botanic Gardens, Kew, with notes on related European species. - Mycol. Pap. 62: $1-216$.
- 1958: Critical notes on some Australian Helotiales and Ostropales. - Kew Bull. 13: 321-358.

- 1963: A redisposition of some fungi ascribed to the Hyaloscyphaceae. - Kew Bull. 17: 319_-379.

- 1968: British Ascomycetes. - 455 pp. Lehre.

- 1980: New or critical fungi from the Highlands and Islands. - Kew Bull. 35(2): 343-361.

- 1981: British Ascomycetes. - $486+40$ pp. Vaduz.

Eckblad, F.-E. 1968: The genera of operculate discomycetes. A re-evaluation of their taxonomy, phylogeny and nomenclature. - Nytt Mag. Bot. 15: 1-191.

Graddon, W.D. 1980: Some new discomycete species 5. Trans. British Mycol. Soc. 74(2): 265-269.

Groves, J.W. \& Hoare, S.C. 1954: Notes on fungi from northern Canada 1. Hypocreales and Discomycetes. Canad. Field.-Nat. 68: 1-8.

Haines, J.H. \& McKnight, K.H. 1977: Notes on two American Hyaloscyphaceae on aspen. - Mycotaxon $5(2): 423-431$

Huhtinen, S. 1982: Ascomycetes from central and northern Labrador. - Karstenia 22: 1-8.

Jeng, R.S. \& Krug, J.C. 1977: New records and new species of coprophilous Pezizales from Argentina and Venezuela. - Canad. J. Bot. 55(24): 2987-3000.

Kallio, P. 1979: Programmes of the Kevo Station. Holarctic Ecology 2: 279-283.

Karsten, P.A. 1871: Mycologia fennica 1, Discomycetes. 263 pp. Helsingfors.

Kohn, L.M. 1982: A preliminaty discomycete flora of Macaronesia 5, Sclerotiniaceae. - Mycotaxon 16(1): 134.

Kohn, L.M. \& Korf, R.P. 1975: Variation in ascomycete iodine reactions: $\mathrm{KOH}$ pretreatment explored. Mycotaxon 3: 165-172.

Korf, R.P. \& Kohn, L.M. 1980: Revisionary studies in the Hyaloscyphaceae 1. On genera with "glassy" hairs. Mycotaxon 10(2): 503-512.

Kullman, B. 1982: A revision of the genus Scutellinia (Pezizales) in the Soviet Union. - Scripta Mycol. 10: $1-158$.

Larsen, H.J. \& Denison, W.C. 1978: A checklist of the operculate cup-fungi (Pezizales) of North America west of the Great Plains. - Mycotaxon 7(1): 68-90.

Le Gal, M. 1941: Les Aleuria et les Galactinia. - Rev. Mycol., Suppl. 6: 56-82.

- 1953: Les Discomycètes de Madagascar. — Prodr. Flore Mycol. Madagascar 4: 1-465.

- 1966: Contribution à la connaissance du genre Scutellinia (Cooke) Lamb. emend. Le Gal (1re étude). - Bull. Soc. Mycol. France 82: 301-333.

Maas Geesteranus, R.A. 1972: Spathularia and Spathulariopsis. - Kon. Nederl. Akad. Wetensch., Ser. C 75(3): $243-255$

Müller, E. \& Dennis, R.W.G. 1959: Pilze aus dem Himalaya 3. - Sydowia 13(1-6): 41-50.

Nannfeldt, J.A. 1976: Iodine reactions in ascus plugs and their taxonomic significance. - Trans. British Mycol. Soc. $67(2): 283-287$.

Petersen, P.M. 1970: Danish fireplace fungi. An ecological investigation on fungi on burns. - Dansk Bot. Ark. 27(3): 1-97.

Pfister, D.H. 1976: A synopsis of the genus Pulvinula. Occ. Pap. Farlow Herb. Harvard Univ. 9: 1-19.

- 1979: Type studies in the genus Peziza 8-10. Species described by G. Massee, E.K. Cash, and F.J. Seaver, Mycotaxon 9(2): 501-504.

Raitviir, A. 1970: Synopsis of the Hyaloscyphaceae. Scripta Mycol. 1: 1-115.

- 1977: The genus Dasyscyphella. - Eesti NSV Tead. Akad. Toim. Biol. 26(1): 29-35.

Raschle, P. 1977: Taxonomische Untersuchungen an Ascomyceten aus der Familie der Hyaloscyphaceae Nannfeldt. - Sydowia 29(1-6): 170-236.

Rehm, H. 1896: Ascomyceten: Hysteriaceen und Discomyceten. - In: Dr. L. Rabenhorst's KryptogamenFlora von Deutschland. Österreich und der Schweiz 3. (2 ed.) -1275 pp. Leipzig. 
Rifai, M.A. 1968: The Australasian Pezizales in the Herbarium of the Royal Botanic Gardens Kew. - Verh. Kon. Nederl. Akad. Wetensch., Afd. Natuurk. 2, 57: 1295.

Schumacher, T. 1979a: Notes on taxonomy, exology, and distribution of operculate discomycetes (Pezizales) from river banks in Norway. - Norw. J. Bot. 26: 53-83.

- 1979b: Phialea granigena, an older name for Gloeotinia temulenta. - Mycotaxon 8(1): 125-126.

Seaver, F.J. 1961a: The North American cup-fungi (Operculates). Supplemented ed. - 377 pp. New York.

- 1961b: The North American cup-fungi (Inoperculates). Supplemented ed. $-428 \mathrm{pp}$. New York.

Svrček, M. 1948: Ceské druhy podčeledi Lachneoideae (čel. Pezizaceae). Bohemian species of Pezizaceae subf. Lachneoideae. - Sbor. Nár. Muz. Praze 4B(6): 1—95.

1971: Tschechoslowakische Arten der Diskomyzetengattung Scutęllinia (Cooke) Lamb. emend. Le Gal (Pezizales) 1. Ceskoslovenské druhy rodu Scuțellinia (Cooke) Lamb. emend. Le Gal (Pezizales) 1. - Ceská Mykol. 25(2): 77-87.

- 1976: A revision of species of the genus Peziza Dill. ex St-Amans, described by J. Velenovský 2 . Revize druhu rodu Peziza Dill, ex St-Amans, popsaných J. Velenovským 2. - Ceská Mykol. 30(3-4): 135-142.

- 1979: A taxonomic revision of Velenovskýs types of operculate discomycetes (Pezizales) preserved in National Museum, Prague. - Sbor. Nár. Muz. Praze 32B (1976): 115-194, Tab. $1-8$.

Svrček, M. \& Kubicka J. 1965: Fimaria porcina sp. nov. (Discomycetes). - Ceská Mykol. 19: 212-215.

Surč́k, M. \& Moravec, J. 1969: Species novae Discomycetum (Pezizales) e Bohemia. - Ceská Mykol. 23: $156-159$.

de la Torre, M. \& Calonge, F.D. 1978: Fimaria hispanica (Ascomycetes) sp. nov. - Anal. Inst. Bot. Cavanilles 34(2): 387-392.

Velenovský, J. 1934: Monographia Discomycetum Bohemiae $1-2$. -436 pp., Tab. 1-31. Pragae.

Weber, N.S. 1972: The genus Helvella in Michigan. Michigan Bot. 11: 147-201.

Webster, J., Rifai, M.A. \& El-Abyad, M.S. 1964: Culture observations on some Discomycetes from burnt ground. - Trans. British Mycol. Soc. 47(3): 445-454.

White, W.L. 1941: A monograph of the genus Rutstroemia (Discomycetes). - Lloydia 4: 153-240.

Accepted for publication

on July 22, 1983 